\title{
AS MINAS GERAIS SETECENTISTAS: GEOGRAFIA E LITERATURA NA OBRA DO INCONFIDENTE CLÁUDIO MANUEL DA COSTA
}

\author{
Kárita de Fátima Araújo \\ Doutoranda do PPGEO/UFU \\ karitafaraujo@hotmail.com
}

Rita de Cássia Martins de Souza

Prof. ${ }^{a}$ Dr. ${ }^{a}$ do IG/UFU

ritacmsou@gmail.com

\begin{abstract}
RESUMO
Objetivando compreender a maneira pela qual se processou a formação territorial brasileira no contexto das Minas Gerais setecentistas, buscou-se fazê-lo à luz da obra literária Vila Rica, de Cláudio Manuel da Costa, no intuito de entrecruzar geografia e literatura, aliando as manifestações artísticas dos agentes que participaram efetivamente da Inconfidência Mineira aos componentes espaciais e temporais que compuseram a sociedade mineira do século XVIII. Nesse sentido, sua poesia foi fundamental para analisar a condição da capitania mineira tal qual ela se apresentava. Alguns elementos foram valiosos para auxiliar nessa análise, tais como, a compreensão do conceito de sertão para aquela localidade e período, bem como, sua ocupação e isolamento; o desenvolvimento e decadência do "ciclo do ouro" e as relações estabelecidas entre as Minas Gerais e as capitanias de São Paulo e Rio de Janeiro para, posteriormente, comporem juntas, uma mesma nação independente de Portugal. Além, da valorização frequente aos bandeirantes paulistas, por sua bravura e disposição em enfrentar o sertão praticamente inexplorado, em uma tentativa do poeta de delinear qual povo deveria compor a nação independente.
\end{abstract}

Palavras-chave: Poesia; Inconfidência; Formação Territorial.

\section{THE MINAS GERAIS OF THE EIGHTEENTH CENTURY: GEOGRAPHY AND LITERATURE IN THE WORK OF THE MEMBER OF THE INCONFIDÊNCIA MINEIRA CLÁUDIO MANUEL DA COSTA}

\begin{abstract}
Trying to understand the way in which they sued the Brazilian territorial formation in the context of Minas Gerais of the eighteenth century, it sought to do it in the light of literary Vila Rica of Cláudio Manuel da Costa, in order to intersect geography and literature, combining demonstrations artistic agents who participated effectively in the Inconfidência Mineira to spatial and temporal components that made up that society of the eighteenth century. In this sense, his poetry was essential to examined the condition of the captaincy such as it was presented. Some elements were valuable to aid in this analysis, such as understanding the concept of sertão for that locale and period, as well, as it condition of occupation and isolation; the development and decay of the "gold rush" and the relations established between Minas Gerais and the captaincy of São Paulo and Rio de Janeiro in order to subsequently compose together a single independent nation of Portugal. In addition, the frequent appreciation to São Paulo pioneers, for their bravery and willingness to face the virtually untapped sertão in an attempt of the poet to outline what people should compose the independent nation.
\end{abstract}

Keywords: Poetry; Inconfidência; Territorial Formation.

Recebido em 28/06/2015

Aprovado para publicação em 06/11/2015 


\section{INTRODUÇÃO}

Com o propósito de resgatar, a partir da poesia do inconfidente Cláudio Manuel da Costa o modo pelo qual se processou a formação territorial brasileira no contexto das Minas Gerais do século XVIII, transitamos entre a geografia e a literatura aliando as manifestações artísticas presentes no discurso literário aos conceitos geográficos, no intuito de compreender aquele determinado espaço e período. Nesse sentido, a obra de Cláudio Manuel da Costa - Vila Rica, foi fundamental para que dentro dos limites temporais e espaciais estabelecidos, pudéssemos enveredar pelos caminhos das Minas setecentistas, compreendendo a capitania das Minas Gerais, tal qual ela se apresentava naquele momento com suas peculiaridades, limitações e intersecções com as demais regiões da colônia.

A obra literária em questão é fruto de um período ímpar na construção da nacionalidade e da identidade brasileiras, marcado por um movimento de suma importância no processo histórico e sócio espacial: a Conjuração Mineira, de 1789. Mais do que refletir a visão do mundo de seu autor, Vila Rica, de Cláudio Manuel da Costa, é um discurso acerca do espaço das Minas Gerais dos setecentos, escrito por um intelectual / indivíduo expressivo que vivenciou as contradições, incertezas e temeridades de um movimento emancipacionista de tamanha grandeza e importância, até então inédito na colônia.

Vila Rica se trata de uma composição que ao retratar a Vila Rica das Minas Gerais (atual município de Ouro Preto) tornou aquela terra, "digna de ser cantada em metro heróico, com fôlego épico de fazer inveja às ninfas do Tejo" (ALCIDES, 2003, p. 29). O poema é escrito no intento de chamar a atenção para os inúmeros feitos heroicos daqueles que ousaram desbravar o sertão mineiro. Cláudio Manuel da Costa revela a todo o momento os desafios enfrentados durante a descoberta e exploração do ouro. O poeta, demonstrando uma "preocupação civilizacional" (ALCIDES, 2003, p. 29), já verificada em outros poemas como o Parnaso, deixa transparecer em Vila Rica o desejo em levar ao sertão alguma ocupação e ordem, exaltando os desbravadores que ali se arriscaram e iniciaram a colonização.

Os literatos inconfidentes, Cláudio Manuel da Costa assim como os demais, Inácio José de Alvarenga Peixoto e Tomás Antônio Gonzaga, deixaram transparecer em suas obras aquilo que Goldmann (1979) chamou de visão do mundo, refletindo nas mesmas, sua percepção de acontecimentos históricos e sociais daquele período. O discurso produzido por esses autores sobressaiu-se aos demais, amplificando-se. Eles apresentam-se como indivíduos expressivos, detentores dos discursos dominantes em dada época e sociedade.

As obras literárias e artísticas são, portanto, as expressões das "visões do mundo" de seus criadores. Visões estas, que nas obras dos poetas inconfidentes procuraram retratar características específicas da região do ouro, bem como, do povo que ali habitava. Sua formação social, religiosa, cultural e até militar, foi fundamental para compor uma gente com forte espírito nacional e com "sentimento de disciplina e de ordem" (LIMA JÚNIOR, 1965, p. 167).

A partir destas observações, e da própria vivência naquele cenário, passaram a existir razões particulares a cada autor para que cada um tivesse sua "visão do mundo" específica. Razões estas, que compõe um "conjunto de aspirações, de sentimentos e de ideias que reúne os membros de um grupo (mais frequentemente, de uma classe social) e os opõe a outros grupos" (GOLDMANN, 1979 p. 20). Para encontrar estas razões, é necessária a análise da trajetória pessoal do autor.

O contexto social e histórico em que viveu o autor é imprescindível, uma vez que, os fenômenos não podem ser compreendidos alheios à sua historicidade. Segundo Goldmann (1979) "uma ideia, uma obra só recebe sua verdadeira significação quando é integrada ao conjunto de uma vida e de um comportamento" (GOLDMANN, 1979, p. 08). A interação do autor com o meio social em que vive, delineia seu pensamento e isso transparece na obra artística.

Entendendo que a arte é uma das responsáveis por favorecer a "tomada de consciência" de um grupo, faz-se necessário compreender ainda, as concepções filosóficas presentes nas narrativas. Dessa maneira, aliando esses três elementos torna-se possível analisar de forma mais profunda o discurso presente nas obras literárias. Já que, o discurso é o próprio objeto de trabalho do escritor e está repleto de concepções e "visões do mundo". Como salientou Sevcenko (1983, p.20), a literatura, "[...] constitui possivelmente a porção mais dúctil, o limite

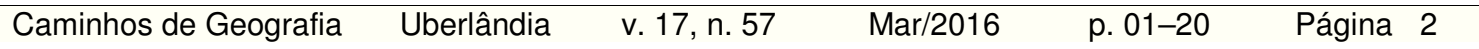


mais extremo do discurso, o espaço onde ele se expõe por inteiro, visando reproduzir-se mas expondo-se igualmente à infiltração corrosiva da dúvida, e da perplexidade. É por onde o desafiam também os inconformados e os socialmente mal-ajustados".

Por meio da literatura é possível analisar as tensões existentes em uma sociedade. A maneira como o autor escreve suas obras e deixa refletir nelas o que ocorre a sua volta se torna uma ferramenta preciosa para compreendermos os embates que se davam ao tempo e quais encontraram eficácia política, ou seja, materializaram-se sobre o território (ANSELMO, 2012).

Ao adotar a literatura como fonte histórica e objeto de pesquisa, Murari $(2009$, p. 37) aponta para a urgente necessidade de "abandonar o preconceito crítico do isolamento do texto literário", considerando-o enquanto um reflexo da cultura, do tempo e da própria concepção do autor. Reconhecendo na narrativa literária, as referências estéticas e temáticas que são representações da realidade, tal qual ela é "percebida e interpretada pelos produtores da arte e do conhecimento" (CASANOVA, 1999 apud MURARI, 2009).

\section{AS MINAS GERAIS DOS SETECENTOS: SERTÃO E MINERAÇÃO}

As Minas Gerais dos setecentos compunham um espaço vasto e praticamente inexplorado até a descoberta de metais preciosos e a vinda de grande contingente populacional em busca das riquezas ali existentes. Abreu (1954) afirma que:

Os primeiros ocupadores do sertão passaram a vida bem apertada; não eram os donos das sesmarias, mas escravos ou prepostos. Carne e leite havia em abundância, mas isto apenas. A farinha, único alimento em que o povo tem confiança, faltou-lhes a princípio por julgarem imprópria a terra à plantação de mandioca [...] (ABREU, 1954, p. 217).

Furtado (2003) ressalta que a economia mineira foi responsável por inaugurar um ciclo migratório europeu totalmente novo na colônia. Segundo o autor, Portugal compreendeu que a única alternativa para que a colônia saísse do estado de prostração que se encontrava, recaia na descoberta de metais preciosos. Isso "explica a extraordinária rapidez com que se desenvolveu a economia do ouro nos primeiros decênios do século XVIII" (FURTADO, 2003, p. 79).

Ainda assim, as dificuldades enfrentadas por aqueles que viram no sertão uma possibilidade de descobrir riquezas e construir um patrimônio, teriam sido menores se, desde o início da ocupação, a Coroa Portuguesa tivesse se colocado à frente da empreitada. Portugal, entretanto, foi no sentido oposto, ocupando efetivamente o litoral em detrimento do interior devido à própria necessidade de inserção da metrópole portuguesa e do Brasil colônia na Divisão Internacional do Trabalho (DIT), feita a partir do cultivo da cana-de-açúcar nos solos férteis do litoral.

Verifica-se, portanto, que anteriormente à descoberta do ouro nas Minas Gerais, os maiores núcleos de povoação se encontravam no litoral do país, de modo que, o interior era ainda pouquíssimo explorado e ocupado por populações indígenas e locais de colonização isolados geralmente ligados a atividades agropecuárias (FONSECA, 2011).

A região das minas de ouro aparece, nesse sentido, como uma área de trânsito (MORAES, 2008 , p. 69), uma vez que, sua ocupação não era ordenada e a colonização era não consolidada em um primeiro momento. A busca por mão-de-obra e posteriormente por pedras preciosas fez com que a região atraísse esse intenso deslocamento populacional, originando uma ocupação descontínua.

Somente no início do século XVIII, com a descoberta pelos bandeirantes paulistas dos primeiros locais de extração, começaram a surgir algumas concentrações humanas onde antes só havia terras inexploradas. Como a ocupação ocorria na medida em que eram descobertas novas minas de ouro, surgiam concomitantemente, áreas de produção agrícola, pecuária e também comercial, para suprir as necessidades das novas povoações. Esse processo de colonização na região ocorria na medida em que um grupo humano ocupava um novo território, tendo em vista que, ao avançar sobre um espaço novo, procuravam incorporá-lo ao seu local de habitação.

$\begin{array}{llllll}\text { Caminhos de Geografia } & \text { Uberlândia } & \text { v. 17, n. } 57 & \text { Mar/2016 } & \text { p. 01-20 } & \text { Página } 3\end{array}$


O povoamento ocorria a partir dos acampamentos dos mineiros e tropeiros, que com o passar do tempo se organizavam e se transformavam em povoações mais estáveis. Não havia, em um primeiro momento, uma preocupação sequer da própria Coroa Portuguesa em ocupar ordenadamente o território. Assim sendo, "o deslocamento das fronteiras do povoamento na colônia portuguesa não se fez de modo linear e contínuo" (FONSECA, 2011, p. 54).

Tais povoamentos iniciaram-se a partir das expedições dos bandeirantes que se aventuravam por aquelas terras. Segundo Holanda (2000), "as expedições realizadas a esse tempo [...] independeram largamente das iniciativas oficiais e visaram menos à busca de ouro, prata e pedras coradas do que à captura do gentio para as lavouras naquela e em outras regiões" (HOLANDA, 2000, p. 54).

Bandeiras como a de Fernão Dias foram extremamente importantes, pois, ao adentrarem no território e descobrirem caminhos e lugares ainda "inexistentes", levando a criação de paradas e arraiais - que posteriormente se tornariam vilas - foram responsáveis por interligar regiões diferentes do Brasil, deixando-o "ligado de Norte a Sul pelo interior" (LIMA JUNIOR, 1965, p. 31).

Essa ocupação, como aponta Furtado (2003), foi impulsionada pela emigração dos paulistas em massa, "do Nordeste se deslocaram grandes recursos, principalmente sob a forma de mãode-obra escrava, e em Portugal se formou pela primeira vez uma grande corrente migratória espontânea com destino ao Brasil. O facies da colônia iria modificar-se fundamentalmente" (FURTADO, 2003, p. 79).

O que era considerado sertão, interior selvagem e desconhecido, foi sendo delineado a partir de um povoamento de incorporação de novas áreas aos territórios já ocupados, o que foi definido por Fonseca $(2011$, p. 66) como um movimento "centrífugo", partindo dos centros mineradores para as zonas circunvizinhas. Paralelamente à extração do ouro surgiram outras atividades que contribuíram para o desenvolvimento da região mineradora, tais como, a pecuária e a agricultura de subsistência, sendo que, ambas se desenvolveram e criaram mercados consumidores.

Tão rápido quanto se descobriu o ouro, povoou-se a região de Vila Rica (Ouro Preto) e, "trataram, logo, de fazer plantação, frutificar a terra e cultivá-la, para haverem de se sustentar e habitar nela" (SARMENTO, 1735 apud LIMA JÚNIOR, 1996, p. 59). Conforme os povoamentos cresciam, e a busca por ouro atraía cada vez mais viajantes em busca das riquezas, o interesse da Coroa portuguesa em controlar e administrar esse território em expansão se intensificava.

Furtado (2003) afirma que a mineração oferecia possibilidades para pessoas com recursos limitados. Pois, o metal explorado, ao contrário do que acontecia no Peru e no México, era o metal de aluvião encontrado no fundo dos rios. Segundo o autor, "tudo indica que a população colonial de origem europeia duplicou no decorrer do século da mineração" (FURTADO, 2003, p.80). A partir do século XVIII, no intuito de controlar socialmente a zona mineradora, a Coroa passou a utilizar um mecanismo bastante eficaz: o poder eclesiástico.

Além de garantir que os habitantes das terras longínquas fossem catequizados, a religião serviria para vigiar de perto as ações naquele território. Diferentemente do que ocorreu no litoral do país, onde a Igreja acompanhou e liderou o processo de ocupação e territorialização, no interior, ela apenas se apossou de uma estrutura que já estava organizada. Assim, conforme as primeiras vilas eram criadas, subordinadas aos ditames da Coroa e da Igreja, cada qual passava a ter também seus "concelhos" ${ }^{2}$ e sua autonomia administrativa, seguindo o modelo utilizado em Portugal. Concomitantemente à criação dessas vilas, surgiram cada vez mais arraiais: pequenas povoações dependentes de uma sede de concelho, que, por sua vez, também estavam submetidas aos interesses da metrópole.

A partir de então, contando com a iniciativa dos habitantes da região das zonas do ouro, capelas foram erguidas, irmandades foram criadas e religiosos passaram a ser remunerados por suas celebrações. Paula (2000) destaca a importância decisiva dessas irmandades, que eram "... talvez, as mais importantes instituições da sociedade civil de então [...] capazes de

\footnotetext{
${ }^{2}$ Também chamados de cidades, vilas, coutos e honras. [...] Eram as células básicas da organização político-territorial portuguesa, e foram, mais tarde, também chamados municípios (FONSECA, 2011, p. 27).
}

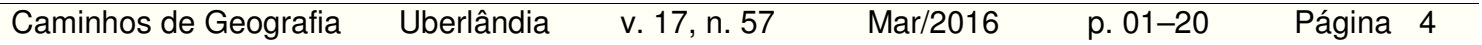


garantir algum grau de organização autônoma, de busca de defesa e interesses coletivos etc" (PAULA, 2000, p. 49).

Cabe destacar que, a região mineradora possuía a maior parte das "sedes paroquiais". Diversas capelas surgiram em Ouro Preto, Rio das Mortes e Serro. De modo que, os arraiais mais "estáveis" encontravam-se nas principais regiões auríferas - ao longo da serra do Espinhaço. Além disso, a maior parte das "freguesias coladas" ${ }^{3}$ que se encontravam nas zonas mineradoras foi criada na primeira metade do século XVIII, apogeu da produção aurífera e período de muitas revoltas em Minas Gerais. Justifica-se, portanto, a criação de tantas paróquias com padres de confiança para supervisionar a região (FONSECA, 2011).

Entre os anos de 1711 e 1730 foi quando surgiram mais da metade das vilas que tiveram seu início com a povoação nos núcleos mineradores ao longo da Serra do Espinhaço (antes mesmo da autonomia da capitania em relação a São Paulo, que ocorreu em 1720). Em 1711, Ribeirão do Carmo (atual Mariana), Vila Rica (atual Ouro Preto) e Vila Real do Sabará (atual Sabará), foram "agraciadas" com o título de primeiras municipalidades ${ }^{4}$ da capitania de Minas Gerais (FONSECA, 2011).

Já em meados de 1750, quando a crise da produção aurífera começou a se anunciar, "devido a uma lenta diminuição do capital aplicado no setor minerador" (FURTADO, 2003, p. 90) houve uma expansão da área de exploração e ocupação, avançando para regiões ainda desconhecidas, limítrofes da capitania. Isso se deveu principalmente ao fato da Coroa Portuguesa fiscalizar de perto as movimentações humanas e a extração das pedras nas regiões mais ocupadas da capitania. Diante disso, uma parte da população saiu das "zonas centrais" em direção a outras localidades, na esperança da descoberta de novas jazidas, além da procura por terras propícias à agricultura. Assim, o território ocupado acabou sendo ampliado, o que aumentou a contribuição para a Coroa.

Nesse período, os arraiais que surgiram estavam localizados na porção sul da capitania e não houve a criação de tantas vilas como ocorreu no meio século anterior. Isso se deveu ao povoamento que ocorreu de maneira disseminada por regiões periféricas da capitania, geralmente ligado às atividades comerciais e agrícolas e não tanto à mineração. Deve-se salientar que, essas atividades paralelas à mineração que vinham se desenvolvendo, foram fundamentais para que a economia mineira não se estagnasse diante do declínio da produção aurífera (FONSECA, 2011).

Ainda assim, os novos arraiais que surgiam, ligados principalmente à agricultura, encontravamse mais dispersos do que aqueles voltados para a mineração, uma vez que, necessitava-se de mais "espaço" para desenvolver atividades agrícolas. Furtado (2003, p. 90) ressalta que esse foi o resultado de toda atrofiação sofrida pela economia mineradora naquele período. E sugere que, caso ela houvesse se desdobrado em um sistema mais complexo, não teria se tornado uma economia de subsistência.

Assim, diferentemente de outras regiões do estado, como o Triângulo Mineiro ou Zona da Mata, que vieram a ser efetivamente ocupadas apenas no século XIX, a região da mineração conheceu esse processo pelo menos um século antes. Deste modo, segundo Paula (2000), "a realidade urbana e regional mineira terá vários momentos, cada qual configurado por uma estruturação-hierarquização, por um perfil de fluxos e interações" (PAULA, 2000, p. 42).

Toda esta configuração urbana surgiu, portanto, em função da zona da mineração. Os diversos núcleos de povoamento que apareceram em um primeiro momento, dispersos pelo território, começaram a se adensar conforme novos locais de extração eram descobertos e assim, novos povoados, arraiais, vilas e posteriormente cidades eram erigidos (PAULA, 2000, p. 41).

Esses núcleos de povoamento imprimiram naquele espaço marcas próprias, resultado de um processo iniciado pela mineração e continuado através das atividades subsequentes -

\footnotetext{
${ }^{3}$ Ou "colativas". Eram as paróquias em que os padres eram "colados" ou "perpétuos", nomeados pelo rei e beneficiários da côngrua (benefícios eclesiásticos) (FONSECA, 2011).

${ }^{4}$ Corresponde a uma autarquia local, independente, ao contrário dos concelhos que eram administrados pelos municípios.
}

\begin{tabular}{|c|}
\hline Caminhos de Geografia \\
\hline
\end{tabular}


comércio e agricultura. Constituiu-se assim, uma "rede" de núcleos urbanos que modificou o espaço da zona da mineração, determinando para esta "região" fluxos específicos de pessoas e mercadorias. Quaisquer que fossem a natureza das "asperezas" deixadas naquele espaço, elas foram fundamentais para "determinar a criação de novas unidades territoriais e a (re) definição dos seus limites" (FONSECA, 2011, p. 87). Considera-se aqui, a definição formulada por Santos (1988):

\begin{abstract}
As rugosidades nos oferecem, mesmo sem tradução imediata, restos de uma divisão de trabalho internacional, manifestada localmente por combinações particulares do capital, das técnicas e do trabalho utilizados (...). O espaço, portanto é um testemunho; ele testemunha um momento de um modo de produção pela memória do espaço construído, das coisas fixadas na paisagem criada (SANTOS, 1988, p. 138).
\end{abstract}

As "rugosidades espaciais" do "ciclo do ouro" apareceram como sendo os frutos das diversas intervenções dos desbravadores, desde as "picadas" que foram abertas para adentrar no terreno, passando pelas estradas - que se tornaram necessárias para transportar pessoas, alimentos, e a própria produção - até a instalação dos primeiros arraiais e vilas da região do ouro. Todas essas intervenções correspondem àquilo que Moraes (2008) classificou como sendo um processo de valorização do espaço, resultante do trabalho humano que à medida que ocorria agregava valor e resultava em formas específicas. Segundo o autor:

Toda sociedade para se reproduzir cria formas, mais ou menos duráveis, na superfície terrestre, daí sua condição de processo universal. Formas que obedecem a um dado ordenamento sociopolítico do grupo que as constrói, que respondem funcionalmente a uma sociabilidade vigente a qual regula também o uso do espaço e dos recursos nele contidos, definido seus modos próprios de apropriação da natureza (MORAES, 2008, p. 41).

Assim, a paisagem torna-se a expressão daqueles que a podem controlar, modificar e alterar. O espaço vivenciado cria "rugosidades que duram mais que estímulos e objetivos que lhes deram origem". Esse espaço, "produzido e herdado", possui formas pretéritas com "estoques de valor concentrados pontualmente na superfície da Terra" (MORAES, 2008, p. 41).

\title{
CLÁUDIO MANUEL DA COSTA: POETA E INCONFIDENTE
}

Quem foram os sujeitos que se envolveram em um movimento pela constituição de um território independente no interior da colônia? Em sua maioria, os inconfidentes compunham um grupo constituído por intelectuais, homens de posse, ocupantes de cargos governamentais e engajados na política. Os três poetas envolvidos no movimento, Cláudio Manuel da Costa, Inácio José de Alvarenga Peixoto e Tomás Antônio Gonzaga foram incentivados por suas abastadas famílias a estudar na Europa. Com exceção de Tomás Antônio Gonzaga que nascera em Portugal, veio para o Brasil e para lá retornou a fim de concluir seus estudos, os outros dois iniciaram seus estudos no Rio de Janeiro e em seguida foram "enviados" para o velho continente (LAPA, 1996).

Além de ocuparem posições de destaque na sociedade mineira, expressavam-se através de suas obras poéticas e literárias. Ressalta-se que, em função dos cargos governamentais que ocupavam, a circulação de suas ideias era facilitada, uma vez que, seus discursos ganhavam legitimidade e alcançavam diversas esferas da sociedade. Os três poetas inconfidentes graduaram-se na Universidade de Coimbra, sendo que, Alvarenga Peixoto e Tomás Antônio Gonzaga se conheceram na própria universidade e se tornaram amigos, formando-se em Leis respectivamente em 1767 e 1768. Já Cláudio Manuel da Costa, alcançou a láurea em artes e também obteve o título de bacharel na Faculdade de Cânones de Coimbra (LAPA, 1996).

Após retornarem ao Brasil, já graduados, os poetas ocuparam cargos importantes no governo da capitania das Minas Gerais: Cláudio Manuel da Costa foi por, duas vezes, nomeado secretário do Governo e Tomás A. Gonzaga ocupou o cargo de ouvidor de Vila Rica. Alvarenga Peixoto, por sua vez, após ocupar o cargo de juiz de fora da vila de Sintra, em Portugal, exerceu o magistério nesse mesmo local e, ao chegar às Minas Gerais, ocupou o cargo de

\begin{tabular}{|c|}
\hline Caminhos de Geografia \\
\hline
\end{tabular}


ouvidor da comarca do Rio das Mortes. Dois anos após assumir o cargo, entretanto, abandonou-o no intento de dedicar-se à mineração, agricultura, criação de gado e produção de açúcar e aguardente, tendo constituído grande fortuna em terras e escravos (LAPA, 1996).

A condição econômica dos poetas foi, certamente, decisiva para que eles desenvolvessem sua intelectualidade, colocando-os à frente de cargos políticos que lhes dessem visibilidade e possibilitando-Ihes conhecer a organização governamental da colônia para, anos mais tarde, questioná-la. Pode-se considerá-los como membros da elite existente na época - fruto da exploração do ouro, da agricultura ou da criação de gado. Carvalho (1990, p. 69), afirma que, com exceção de Tiradentes, que possuía um caráter humilde e popular - o que influenciou, inclusive, na construção de sua imagem como mártir do movimento - os demais envolvidos faziam parte da elite econômica e cultural de Minas Gerais.

O Movimento pela Inconfidência teve um caráter "conservador", idealizado e organizado no seio da alta sociedade mineira dos setecentos. Assim, como salienta Valadares (2001), a insatisfação que permeava a sociedade mineira como um todo - devido às práticas abusivas dos governantes e à condição econômica já decadente das Minas Gerais - atingiu diretamente as famílias mais abastadas com as excessivas espoliações tributárias, "fazendo com que se criasse, entre os membros das elites, um ambiente de insatisfação" (VALADARES, 2001, p. 173).

A família de Cláudio Manuel da Costa descendia de portugueses e de paulistas, "pertencentes à primeira geração dos mineiros" (RIBEIRO, 1996, p. 09), o que lhes possibilitou acumular um significativo patrimônio. Tomás A. Gonzaga, descendia de ingleses, portugueses e brasileiros, sendo que, seu pai ocupava o cargo de juiz de fora em Montalegre (Portugal), o que lhe possibilitou oferecer a seu filho a possibilidade de estudar e se graduar. Já Alvarenga Peixoto era o mais abastado dos três poetas, visto que, além de grande herança deixada pelo pai, possuía familiares abastados, herdeiros de sesmarias em Minas e Goiás (LAPA, 1996).

Como se vê, a trajetória desses poetas, que constituíram ao lado de outros como José de Santa Rita Durão a chamada Escola de Minas, foi fundamental para constituir "não só uma vida material mais ativa, como também um desenvolvimento considerável de cultura intelectual. Partiram precisamente dessa província os movimentos revolucionários e as tentativas de independência, à frente dos quais se colocaram esses poetas" (CÉSAR, 1978, p. 153).

\section{ARCADISMO COMO POSSIBILIDADE DE MANIFESTAÇÃO ARTíSTICA DOS POETAS INCONFIDENTES}

O século XVIII foi marcado pelo início da consolidação da literatura brasileira. Literatura esta que se desenvolveu sob os moldes do lluminismo vindo da Europa e foi denominada Arcadismo. Suas origens advêm de Lisboa, da Arcádia Lusitana (1756) e teve como objetivo "combater o artificialismo, a falsa argúcia e o palavreado oco que haviam chegado às tendências barrocas na sua fase de decadência" (CÂNDIDO, 2010, p. 34).

O Arcadismo pode ser dividido em dois momentos: o poético e o ideológico. Segundo Bosi (1980), o primeiro reflete o encontro com a natureza e o segundo traduz a crítica da burguesia culta aos abusos do clero e da nobreza. Sendo que, o segundo momento parece-nos mais interessante visto que, parte daí o engajamento necessário para que os literatos inconfidentes revelassem em suas obras suas críticas e sátiras contra o governo metropolitano, além de ponderações que revelaram, como no caso de Cláudio Manuel da Costa, uma posição favorável à independência das Minas Gerais.

Além da presença do bucolismo, do clima pastoril e do propósito de retorno às origens presentes no Movimento Árcade, a burguesia insurgente passa a renegar o absolutismo instaurado na Europa, assim como em terras brasileiras os literatos e intelectuais renegam a condição de colônia, envolvendo-se em movimentos como o da Inconfidência. Neste contexto, o campo e a natureza na Europa são cobiçados em contraposição aos novos hábitos citadinos que se consagraram com a Revolução Francesa e Industrial (CẨNDIDO, 1959).

É no momento ideológico do período árcade ou da llustração que, segundo Bosi (1980), formaram-se as bases ideológicas dos árcades brasileiros, como afirma a seguir:

\begin{tabular}{|c|}
\hline Caminhos de Geografia \\
\hline
\end{tabular}


E sem dúvida foram as teses ilustradas, que clandestinamente entraram a formar a bagagem ideológica dos nossos árcades e lhes deram mais de um traço constante: o gosto da clareza e da simplicidade graças ao qual puderam superar a pesada maquinaria cultista; os mitos do homem natural, do bom selvagem, do herói pacífico; enfim, certo mordente satírico em relação aos abusos dos tiranetes, dos juízes venais, do clero fanático, mordente a que se limitou, de resto, a consciência libertária dos intelectuais da Conjuração Mineira (BOSI, 1980, p. 66-67)

O Movimento Árcade, também chamado de Neoclassicismo, surgiu na Itália, no final do século $\mathrm{XVII}$, perdurando durante todo o século XVIII e encerrando-se já no século XIX. Desenvolveuse em terras mineiras em pleno auge do ciclo do ouro. Alguns dos principais autores da época, Cláudio Manuel da Costa, Inácio José de Alvarenga Peixoto, José de Santa Rita Durão, Tomás Antônio Gonzaga e José Basílio da Gama trouxeram do período em que residiram e estudaram em Portugal e em demais países europeus, as tendências libertárias que já vigoravam na Europa e tiveram grande influência na Inconfidência Mineira.

O movimento Inconfidente foi, portanto, influenciado diretamente por esse desenvolvimento intelectual e também material que se apresentou na região das minas naquele momento. Ainda que as bases para o fortificar tenham sido trazidas da Europa, o elevado avanço econômico, intelectual e cultural que ali se instalara, favoreceu atividades ligadas ao intelecto, como poesia, artes plásticas e música.

\title{
O INCONFIDENTE CLÁUDIO MANUEL DA COSTA E O “BRAZIL” INDEPENDENTE
}

A ideia central, cerne do movimento da Inconfidência Mineira, girava em torno da independência. Entretanto, a liberdade do domínio português não se daria sobre toda a colônia, restringindo-se apenas às Minas Gerais e possivelmente às capitanias do Rio de Janeiro e de São Paulo - caso o levante em terras mineiras fosse bem-sucedido e alcançasse as capitanias acima citadas. Afinal, "não há, porém, dados suficientes para se afirmar que o movimento abarcaria toda a América Portuguesa" (RESENDE, 1983, p. 45).

Carvalho (1990) afirma que, os inconfidentes buscavam libertar em um primeiro momento, a capitania das Minas Gerais e juntamente com ela, as de São Paulo e Rio de Janeiro. Isso se deveu segundo o autor, a um cálculo tático, visto que, libertadas as três capitanias - de maior importância na colônia - as demais seguiriam com maior facilidade (CARVALHO, 1990, p. 67).

É bem verdade que articulações vinham sendo feitas fora de Minas Gerais. Tiradentes, que viera fazendo contatos com pessoas influentes na capital do Vice-Reino, afirmava que com a adesão do coronel José Aires, outros poderosos se juntariam ao movimento. No tocante a São Paulo, o tenente-coronel Francisco de Paula se responsabilizaria a contatar amigos que garantiriam a participação dos paulistas no levante (SILVA, 1948).

\begin{abstract}
A expansão do movimento a outras Capitanias era prevista e desejada. Percebia-se, porém, claramente que a possibilidade de articulação só se daria depois de desencadeado o movimento em Minas. O caráter nacional do movimento era o objetivo final de um processo que se desencadearia a partir de Minas Gerais e contaria, preliminarmente pelo menos, com o apoio do Rio de Janeiro e de São Paulo (RESENDE, 1983, p. 45).
\end{abstract}

Ademais, o Padre Toledo, procuraria garantir que contatos fossem feitos em São Paulo por meio de suas relações de família, engrossando o número de participantes. Portanto, o levante que teria início em Vila Rica, espalhar-se-ia por outras localidades da capitania mineira - tais como Serro Frio, Minas Novas, São José, Borda do Campo, Tamanduá - e, posteriormente, chegaria a São Paulo e Rio de Janeiro, garantindo assim, o envolvimento das três mais importantes capitanias da colônia, o que certamente aumentaria as chances de sucesso do mesmo (RESENDE, 1983).

A independência sonhada pelos inconfidentes viria acompanhada da instauração de uma República, nos moldes daquela fundada pelos colonos ingleses da América. Os Estados Unidos serviram de inspiração ao instituírem "uma forma de governo popular e livre, como pregavam os filósofos franceses [...]" (RESENDE, 1983, p. 45).

$\begin{array}{llllll}\text { Caminhos de Geografia } & \text { Uberlândia } & \text { v. 17, n. } 57 & \text { Mar/2016 } & \text { p. 01-20 } & \text { Página } 8\end{array}$


Os inconfidentes, portanto, ao voltarem com interesse seu olhar para o caso norte-americano, bem como, para os ideais liberais que fomentavam os textos dos filósofos europeus do período da Revolução Francesa, pretendiam colocar em prática o "conjunto de idéias [sic] éticas, políticas e econômicas da burguesia, em oposição à visão de mundo da nobreza feudal" (ARANHA; MARTINS, 2003, p. 246), que compunham o liberalismo político da época.

Foi nas idéias [sic] liberais dos pensadores franceses Voltaire, Rousseau, Abade Raynal, e na vitória da Revolução de Independência das 13 Colônias da América, realizada sob influência das mesmas idéias [sic], que os conjurados mineiros encontraram a inspiração ideológica e o modelo do Estado que sonharam criar. Assim, a França foi a origem das ideias políticas e os Estados Unidos, o modelo concreto da prática das idéias [sic] (RESENDE, 1983, p. 42).

Interessante destacar aqui, a diferença essencial entre o desenvolvimento do capitalismo nos países europeus e o andamento do capitalismo no Brasil, por excelência, ainda centrado na exploração agrícola de exportação e na exploração de minérios e matérias primas. Há claramente um descompasso entre as ideias liberais advindas da Europa e o desenvolvimento real do capitalismo entre as áreas em questão, o que de certa forma, inviabilizaria o transplante ipsis litteris dos ideais e das práticas europeias para o Brasil colônia.

Soma-se a isto, o fato de a Revolução Francesa ter incorporado camponeses e operários, ao passo que, o movimento Inconfidente além de ter sido idealizado por membros da oligarquia agrária e mineradora, teria apenas indígenas e escravos para integrar o processo revolucionário. Há que se considerar ainda que, os princípios que delinearam a Revolução Francesa, foram essenciais para a formação da sociedade de classes e do Estado burguês, diferentemente das condições que levaram à formação do Estado para o Brasil do século XVIII.

Mesmo diante de tais contradições, os inconfidentes propuseram alguns projetos de governo que serviriam de suporte para a República que seria implementada nas Minas e possivelmente em São Paulo e Rio de Janeiro. Dentre eles, previa-se a mudança da capital da capitania mineira de Vila Rica para São João d' El Rey, visto que, esta vinha desenvolvendo sua agricultura e pecuária, além de estar localizada em uma área favorável a essas produções. Diversificar e expandir o que era produzido na capitania tornou-se fundamental, uma vez que, a mineração já se encontrava em crise. Havia uma preocupação em instalar manufaturas e fábricas de ferro e pólvora, diminuindo assim, a dependência de produtos importados. (RESENDE, 1983).

Preocupavam-se ainda em equilibrar a população incentivando o aumento da natalidade, visto que, havia um grande contingente de negros e portugueses. Com relação aos negros escravos, os inconfidentes não eram unânimes, havia aqueles que se posicionavam a favor da libertação dos mesmos, já que, mantê-los cativos iria contra os princípios de liberdade propostos para a República. Outros, entretanto, não compartilhavam dessa opinião, uma vez que, libertando-os não haveria mão-de-obra para trabalhar nas minas e nas lavouras. Inquietavam-se também com a possibilidade de os negros libertos organizarem-se entre si e, rebelarem-se contra os demais. Como salienta Resende (1983):

Com a questão da alforria transparece a questão da marginalidade do negro. A visão é a de que a população negra, escrava ou forra, poderia potencialmente, ameaçar a revolução dos colonos brancos, talvez até combatendo ao lado dos portugueses. Libertar os escravos para obter apoio e correr o risco de ficar sem mão-de-obra era, em síntese, o problema colocado por alguns conjurados (RESENDE, 1983, p. 46).

Após delinear os ideais que fundamentariam a construção do Estado desejado, e, algumas diretrizes que norteariam 0 governo, fazia-se necessário conhecer e demarcar estrategicamente o espaço das Minas que abrigaria a Nação independente. Como já sinalizado, este espaço, que comporia o território livre almejado pelos inconfidentes, correspondia, em um primeiro momento, à capitania das Minas Gerais, sendo que, sua configuração não era a mesma que temos hoje no estado.

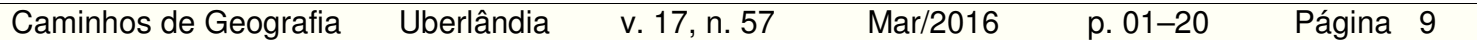


No final do século XVIII e início do XIX, o território mineiro ocupava parte do norte do estado de São Paulo como o conhecemos atualmente e não possuía a porção oeste - correspondente ao Triângulo Mineiro, que pertencia à Goiás. Vale ressaltar que, as áreas localizadas nas porções norte e oeste do estado foram efetivamente ocupadas apenas em meados do século XIX. Em Vila Rica, Cláudio Manuel da Costa ao narrar e exaltar a fundação das Minas Gerais sinaliza em seu "Fundamento Histórico", quais eram as principais vilas que compunham aquele território, bem como, sua localização exata, de que maneira foram ocupadas e quando deixaram de ser arraiais, tendo sido elevadas à condição de Vila.

As quatro Comarcas da Capitania das Minas Gerais se denominavam, Comarca do Rio das Mortes, Comarca de Sabará, Comarca de Vila Rica e Comarca do Serro Frio. As principais vilas que as compunham, sendo consideradas as "cabeças" das Comarcas eram a Vila do Carmo (atual Mariana), Vila Rica (atual Ouro Preto), Sabará, Caeté ou Vila Nova da Rainha, Vila de São João, Vila de São José e Vila do Príncipe (COSTA, 1996).

Cláudio Manuel da Costa salienta a importância de levar ao conhecimento dos leitores tais informações históricas e geográficas e ainda que não fosse sua intenção "[..] cansar ao Leitor [sic] com a multiplicidade dos nomes de tantos que têm a glória de descobridores [...]" (COSTA, 1996, p. 364 - 1를 Edição, 1837), ressalta:

\begin{abstract}
Persuadido o Autor desta obra de que não serão bastantes as notas com que ilustrou os seus Cantos a instruir ao Leitor da notícia mais completa do descobrimento das Minas Gerais, da sua povoação e do aumento a que têm chegado os seus pequenos Arraiais, se resolveu a escrever esta preliminação [sic] histórica, em que protesta não pertender [sic] alterar a verdade a benefício de alguma paixão, e só regula pelo mais crítico e incontestável exame, que por si e por pessoas de conhecida inteligência e probidade pôde conseguir sobre fatos que eu ou a tradição conserva de memória, ou escreveu raramente algum gênio curioso, que o testemunhou de vista (COSTA, 1996, p. 360 - 1ª Edição, 1837).
\end{abstract}

A partir daí o poeta inicia sua narrativa com fidedignidade de nomes, datas e características gerais do descobrimento das Minas. Nesse sentido, a obra literária cumpre um papel que vai além das potencialidades artísticas, revelando-se como um trabalho tradicionalmente tido como científico. Partindo das entradas feitas pelos primeiros paulistas nos sertões ainda inóspitos, durante o século XVII, Cláudio Manuel da Costa valoriza a empreitada por eles realizada dizendo que "são os que nesta América têm dado ao Mundo as maiores provas de obediência, fidelidade e zelo pelo seu Rei, pela sua Pátria e pelo seu Reino" (COSTA, 1996, p. $360-1^{\text {a }}$ Edição, 1837).

O poeta faz um apontamento daqueles que poderiam ser considerados os primeiros paulistas a "descobrir" as Minas Gerais, responsáveis por levar ao conhecimento do Governador do Rio de Janeiro as primeiras amostras de ouro encontradas nas terras mineiras. Os nomes de "Carlos Pedroso da Silveira" e "Bartolomeu Bueno de Siqueira" aparecem como responsáveis por essa empreitada. No Segundo Canto de seu poema épico Vila Rica, Cláudio Manuel da Costa narra a descoberta do ouro no "Córrego do Ouro Preto", ocasião em que "Antônio Rodrigues Arzão", da Vila de Taboaté, penetra os sertões com uma comitiva composta por mais de cinquenta homens. Após a morte de Arzão, entretanto, "Carlos Pedroso Silveira" dá continuidade à empreitada e, estimula os

paulistas a armarem tropas, a prevenirem-se de alguma fábrica mais proporcionada ao uso de minerar, e a desampararem a Pátria, rompendo os matos gerais desde a grande Serra do Lobo, que divide a Capitania de São Paulo, até penetrarem o mais recôndito das Minas, menos já na conquista do Gentio, que na diligência do ouro (COSTA, 1996, p. 363 - 1ª Edição, 1837).

Outro evento que ganha destaque no poema Vila Rica é conhecido como a Guerra dos Emboabas em que paulistas e portugueses (pejorativamente denominados "buabas" ou "emboabas") enfrentaram-se pelo direito de exploração das jazidas recém-descobertas. $O$ autor descreve o conflito em seu "Fundamento Histórico" como sendo fruto da "soberba, da ambição

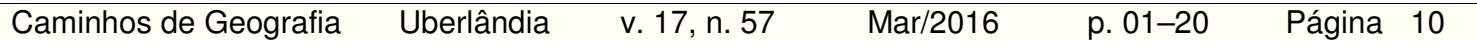


e do orgulho" (COSTA, 1996, p. 369 - 1를 Edição, 1837), que já dominavam àqueles que ali se instalaram.

O descobrimento das esmeraldas, narrado no Canto Oitavo do poema, refere-se à empreitada encabeçada por Fernão Dias Paes, levado ao sertão movido pelo mito do "Sabarabuçu", serra em que haveria uma quantidade inimaginável de pedras preciosas. Cláudio Manuel da Costa transcreve no "Fundamento Histórico", o poema de Diogo Grasson Tinoco, escrito em 1689, sobre a empresa de Fernão Dias, no intento de dar uma ideia do descobrimento das esmeraldas.

Diante da exposição dos detalhes que compunham a região das minas de ouro naquele período, presentes no poema Vila Rica e do interesse de Cláudio Manuel da Costa em relatar com clareza e precisão as características daquela terra e daqueles que a ocuparam, pode-se argumentar que havia intenção por parte do autor em demarcar, mapear e limitar o território das Minas Gerais que comporia a Nação independente almejada por ele e pelos demais inconfidentes.

Novamente em seu "Fundamento Histórico", o poeta traz a localização exata de cada uma das Vilas fundadas nas quatro Comarcas da Capitania mineira, além de destacar aspectos naturais como a fertilidade ou infertilidade da terra, a abundância ou escassez de nascentes, rios, cursos d'água e, claro, a facilidade ou dificuldade em se encontrar ouro e metais preciosos. Vila do Carmo (hoje, Mariana) foi descrita pelo autor como sendo local de difícil acesso devido à

\begin{abstract}
frialdade das águas, despenhadeiros e matos cerradíssimos [sic] que o cercavam (Ribeirão do Carmo) de ambas as margens, tanto, que só permitia trabalhar-se dentro dele quatro horas do dia, além da grande penúria dos mantimentos, que chegou a trinta, e quarenta oitavas o alqueire de milho, e o de feijão a oitenta oitavas, foi fácil desampararem os mineiros por algum tempo a sua Povoação [...] (COSTA, 1996, p. 364 - 1ª Edição, 1837).
\end{abstract}

Traz ainda sua localização, distando-se "este Ribeirão até a barra do Rio Doce 16 té [sic] 18 léguas, e pela volta do Rio se compunham 30. Está situada em 20 graus e 21 minutos ", (COSTA, 1996, p. 364 - 1를 Edição, 1837). Pode-se observar que a povoação da Vila do Carmo ocorreu no entorno do Ribeirão que leva o mesmo nome e que, a produção de víveres e a mineração no rio compunham o sustento dos habitantes.

A Vila Rica (atual Ouro Preto) é descrita como compreendendo "em si vários ribeiros e morros com diferentes denominações, como são Passadez, Bom Sucesso, Ouro Fino, ou Bueno etc." (COSTA, 1996, p. 365 - 1를 Edição, 1837), vê-se aí, a descrição da paisagem acidentada que compõe a região de Ouro Preto. Localidade esta marcada pela abundância de pedras preciosas, situando-se em "20 graus e 24 minutos ao poente" (COSTA, 1996, p. $365-1^{\text {a }}$ Edição, 1837).

Sabará, juntamente com as duas vilas anteriormente citadas foi elevada a esta condição em 1711, justamente por ter sido uma das primeiras ocupações efetivas em terras mineiras. Como salienta Cláudio Manuel da Costa, as primeiras entradas feitas pelos paulistas em busca de indígenas para serem escravizados e, posteriormente em busca de ouro, levaram os desbravadores às margens do Rio das Velhas, fundado nessa região a vila de Sabará, localizada em "19 graus e 52 minutos" (COSTA, 1996, p. 365 - 1ª Edição, 1837) e descoberta por volta de 1700, após seus fundadores terem,

atravessado o dilatadíssimo [sic] sertão do Sabará-Bussu muito antes de qualquer outro das Minas, porque os primeiros conquistadores demandavam o Rio das Velhas, cujas dilatadas campinas eram mais povoadas dos Gentios e férteis de caça, e as primeiras diligencias do ouro e pedras se fizeram ao norte de São Paulo [...] (COSTA, 1996, p. 365-1ª Edição, 1837).

\footnotetext{
${ }^{5}$ Deve-se ressaltar aqui que a localização das vilas tal como apresentadas por Cláudio Manuel da Costa, não é compatível com a que temos hoje, uma vez que, o Meridiano de Greenwich foi estabelecido por George Biddell Airy em 1851 e definido como um acordo internacional apenas em 1884.
}

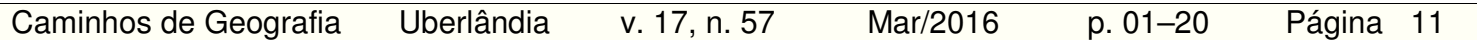


Caeté ou Vila Nova da Rainha, localizada entre "Sabará e o Arraial de Santa Bárbara [...]. Está situada em 19 graus e 55 minutos" (COSTA, 1996, p. 365-366 - 1a Edição, 1837) tendo sido elevada à categoria de vila em 1714. A Vila de "São João está em 21 graus e 20 minutos; São José em 21 e 5" (COSTA, 1996, p. 366 - 1aㅡ Edição, 1837) ambas localizadas nas proximidades do Rio das Mortes e na Comarca que leva o mesmo nome. Por fim, a última vila descrita no poema é àquela denominada Vila do Príncipe, "situada em 18 graus e 23 minutos" (COSTA, 1996, p. 366 - 1를 Edição, 1837) na Comarca do Serro Frio, assim batizada devido à descoberta de Antônio Soares, que, ao atravessar os sertões ao norte de São Paulo

descobriu o grande Serro vulgarmente chamado o do Frio, que na língua gentílica era tratado por Hivituraí, por ser combatido de frigidissimos [sic] ventos, todo penhascoso [sic] e intratável (COSTA, 1996, p. 366- 1aㅡ Edição, 1837).

As riquezas encontradas em abundância nessas terras também foram descritas e valorizadas no poema. Cláudio Manuel da Costa salienta que "as grandes preciosidades deste continente em ouro, diamantes e todo o gênero de pedras estimáveis são bem conhecidas por toda a Europa: nele se estabeleceu o Real Contrato Diamantino ${ }^{6}$, que tem devido aos Senhores Reis de Portugal a maior vigilância e zelo" (COSTA, 1996, p. 366 - 1ㄹ Edição, 1837).

Diante dos escritos do autor no "Fundamento Histórico" de seu poema Vila Rica, vê-se, portanto, o mapeamento do território mineiro, correspondente à região da mineração em desenvolvimento no século XVIII. Mostrava-se uma tarefa de fundamental importância descrever, expor e valorizar diante de seus leitores, as terras que seriam o berço da Nação independente. Vale ressaltar que, as vilas citadas por Cláudio Manuel da Costa são apenas uma parte do território almejado para compor a República. Elas representam localidades descobertas há mais tempo tendo sido elevadas a vilas, devido sua posição estratégica dentro dos caminhos pela busca de pedras preciosas, juntamente com o considerável contingente populacional que nessas localidades se fixou. Havia ainda um grande número de arraiais e povoações de menor porte, que juntos, constituíam a região mineradora.

Interessante frisar que os caminhos percorridos pelos viajantes e desbravadores e que foram posteriormente utilizados para escoar as pedras preciosas extraídas, em direção aos portos no litoral da colônia com destino à Europa, acabaram por criar novos pontos de paragem que se tornariam arraiais e vilas. Essas localidades desenvolveram ainda atividades como agricultura e pecuária que davam suporte à extração do ouro na região. As vilas acima citadas, que aparecem no poema de Cláudio Manuel da Costa, compõem juntamente com outras localidades como Pitangui, Serro, Diamantina e Minas Novas, núcleos hierarquizados que se tornam redes estruturadas, características tipicamente urbanas precocemente observadas na região mineradora dos séculos XVII e XVIII (PAULA, 2000).

Vê-se que tal "rede" se organizou e se desenvolveu formando os caminhos do que foi sendo denominado ao longo da história, como Estradas Reais. As "estradas do ouro" compunham-se, basicamente, de quatro caminhos distintos que durante o ciclo do ouro serviram de passagem para escoar a produção aurífera, bem como, para levar mantimentos e bens manufaturados aos povoados. Os caminhos denominam-se: Caminho Velho, Caminho Novo, Caminho do Sabarabuçu e Caminho dos Diamantes, como se pode observar na (FIGURA 1).

\footnotetext{
${ }^{6}$ O Distrito Diamantino foi oficialmente constituído em 1734, quando a Coroa enviou para o arraial do Tejuco: Martinho de Mendonça Pina e Proença e Rafael Pires Pardinho, a fim de organizar a extração das pedras. Pelo sistema o arraial do Tejuco era a sede da demarcação que tinha seus limites nos arraias de Gouveia, Milho Verde, São Gonçalo, Chapada, Rio Manso, Picada e Pé do Morro, o que poderia ser modificado com a descoberta de novas áreas de extração. Administrativamente o distrito continuou depende da Câmara e da Ouvidoria da Vila do Príncipe e Rafael Pires Pardinho foi nomeado o primeiro intendente dos diamantes. Como os preços internacionais do diamante foram afetados pela exploração livre que inicialmente ocorreu na região, a partir de 1729, a extração só foi reaberta em 1739 quando os preços se normalizaram. A partir desse ano, a mineração das pedras passou a funcionar sobre o sistema de contratos onde particulares arrematavam a extração por quatro anos. Ver: RODRIGUES, Carmem Marques. "Distrito Diamantino". In: BiblioAtlas - Biblioteca de Referências do Atlas Digital da América Lusa. Disponível em:http://hs.unb.br/biblioatlas/Distrito_Diamantino. Data de acesso: 23 de setembro de 2013.
}

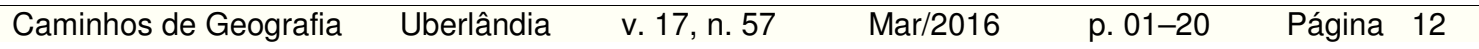


Figura 1. Estrada Real

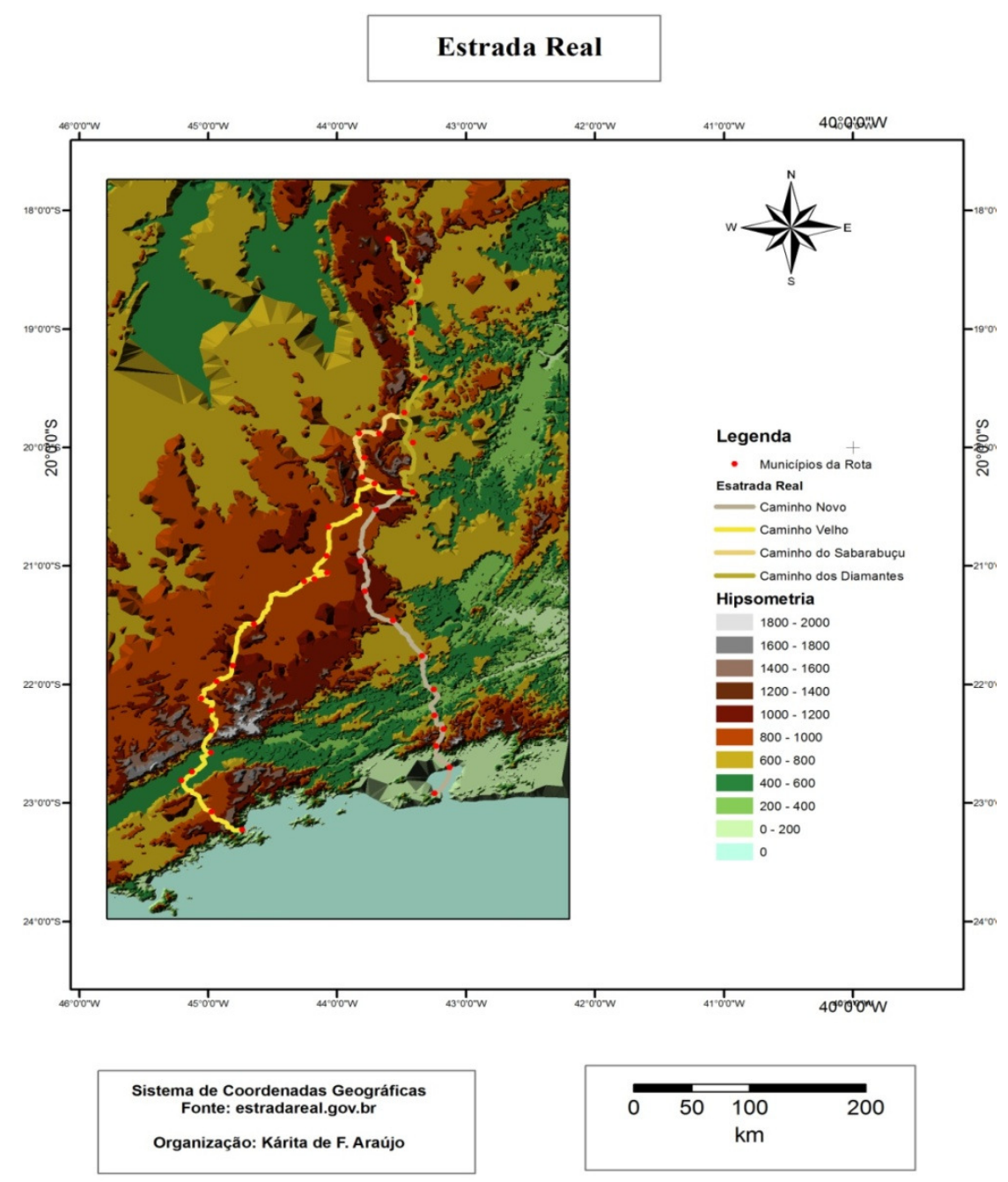

Fonte: ARAÚJO, 2013.

O Caminho Velho foi o primeiro e mais antigo dentre os demais, oficialmente aberto pela Coroa Portuguesa ainda no século XVII, tendo sido utilizado para se atingir o interior da capitania. Originando-se no litoral paulista, mais precisamente em Paraty, o Caminho Velho atravessava municípios como Tiradentes, São João Del Rei, São Lourenço e Passa Quatro, em direção à região mais central da capitania mineira, findando-se em Ouro Preto.

Esse caminho, trilhado pelos viajantes e utilizado para escoar a produção, era o mais longo, a duração da travessia de São Paulo à Ouro Preto ou à região do rio das Velhas era cerca de 74 dias de viagem (COSTA, 2005). Além disso, por ele se percorria áreas de maior altitude (entre $1000 \mathrm{~m}$ e $1400 \mathrm{~m}$ ) o que dificultava o transporte das pedras e das mercadorias. Ademais, após a abertura do porto no Rio de Janeiro, tornou-se inviável o transporte pelo mar entre Paraty e Rio, surgindo a necessidade de utilização de um novo caminho.

Assim surgiu o Caminho Novo, que teve sua abertura autorizada pela Coroa Portuguesa no final do século XVII tendo sido sendo concluído no início do século seguinte, por volta de 1707 (CARVALHO, 2011). Esse caminho, como uma alternativa mais viável ao primeiro, levava cerca de doze dias para ser percorrido (COSTA, 2005) e boa parte da rota passava por áreas de menor altitude, entre $200 \mathrm{~m}$ e $800 \mathrm{~m}$, como se pode observar na figura.

Deve-se destacar que, ao contrário do Caminho Velho - que em um primeiro momento teve um papel de abertura das frentes expansionistas de desbravamento do sertão - o Caminho Novo

$\begin{array}{llllll}\text { Caminhos de Geografia } & \text { Uberlândia } & \text { v. 17, n. } 57 & \text { Mar/2016 } & \text { p. 01-20 } & \text { Página } 13\end{array}$


já foi construído para exercer fundamentalmente o papel de "corredor de exportação", responsável por escoar a maciça produção da região das minas de ouro.

O próprio Cláudio Manuel da Costa percorreu o Caminho Novo durante sua viagem de volta de Lisboa, em direção à Vila Rica, no ano de 1754, tempos depois de o mesmo ter sido inaugurado, o que não diminuía a dificuldade da viagem. Tendo partido o poeta, durante 0 verão - a estação das chuvas naquela região, o caminho que saía do Rio de Janeiro, transformava-se em um verdadeiro pântano, tendo poucos trechos carroçáveis e sendo feito, em sua grande parte, a pé, em meio aos lamaçais. Na ocasião, o poeta que já se encontrava relutante em retornar ao Brasil, ao deparar-se com tal situação, ponderou: "Não são estas as venturosas praias da Arcádia..." (ALCIDES, 2003, p. 111).

Há ainda dois outros caminhos que compõem a Estrada Real e devem ser destacados. Um deles é o Caminho do Sabarabuçu, que liga o Caminho Velho ao dos Diamantes por um pequeno trecho que sai da região de Ouro Preto, com destino ao município de Caeté. O Caminho do Sabarabuçu leva o mesmo nome da serra lendária que motivou diversas expedições à região, inclusive a mais conhecida delas, liderada por Fernão Dias.

Por último, há o Caminho dos Diamantes, localizado mais ao norte da capitania mineira, ligando o município de Diamantina à Ouro Preto. O trajeto passa por municípios como Bom Jesus do Amparo, Santa Bárbara e Mariana. Esse Caminho começou a ser utilizado em meados da década de 30 do século XVIII com a descoberta e extração de diamantes naquela região. O chamado "distrito dos diamantes" teve sua primeira delimitação feita em 1737 e foi sucessivamente ampliado em função da descoberta de novas jazidas (FONSECA, 2011).

Os mais de $1500 \mathrm{~km}$ que com a união desses quatro caminhos compõe a Estrada Real, estendendo-se desde o sul da então capitania de Minas Gerais até o interior do estado, atravessam ainda as capitanias de São Paulo e Rio de Janeiro, passando por municípios como Lorena e Guarantiguetá em São Paulo e Itaipava e Petrópolis no Rio de Janeiro.

Esses caminhos, hoje definidos com certa facilidade, foram sendo traçados ao longo dos anos de acordo com as expedições realizadas e a descoberta de novas jazidas. Abreu (1989) salienta que "os primeiros descobertos lavraram-se em águas do rio Doce, do rio das Velhas, mais tarde, do rio das Mortes e do Jequitinhonha" (ABREU, 1989, p. 45). A bacia do rio Doce, por exemplo, abrange municípios como Ouro Preto e Mariana, enquanto que, o rio das Velhas tem suas nascentes localizadas também em Ouro Preto, passando ainda por Sabará, outro município de importância durante o ciclo do ouro.

O rio das Mortes também perpassa por localidades de relevância da época, tais como, São João Del-Rei, Tiradentes e Barbacena. O rio Jequitinhonha, por sua vez, localizado mais ao norte do estado de Minas Gerais, tem suas nascentes próximas à Diamantina e Serro. Como se vê, os quatro rios mencionados atravessam ou situam-se próximos aos municípios que, no século XVIII, compunham o cenário da exploração do ouro. Como afirmado por Abreu (1989), o rio Jequitinhonha foi, juntamente com o rio das Mortes, os últimos a serem alcançados, visto que, as bandeiras partiam do sul em direção ao norte da capitania.

Portanto, os caminhos traçados pelos viajantes e exploradores "coincidiram", muitas vezes, com o próprio curso dos rios, já que, os mesmos acabaram por levar até a região central do estado onde foi encontrada maior abundância de pedras preciosas. Ademais, rios como o Doce e o das Mortes - que nascem na Serra da Mantiqueira, estão localizados em áreas onde foram descobertas diversas jazidas de importância para o período.

Os caminhos da Estrada Real, entretanto, não se compunham apenas das vilas e arraiais das Minas Gerais que vinham prosperando graças ao ouro descoberto. A capitania de São Paulo, segundo Abreu (1989), já possuía grande número de vilas anteriores a 1680, tais como, Moji das Cruzes, Parnaíba, Taubaté, Guaratinguetá, Itu, Jundiaí e Sorocaba. Cada vila, por sua vez, possuía a função de direcionar os viajantes para partes específicas do território, "as vilas do Paraíba do Sul apontavam para as próximas Minas Gerais, como Parnaíba e Itu apontavam para Mato Grosso, como Jundiaí apontava para Goiás, e Sorocaba para os campos de pinheiros em que já surgia Curitiba" (ABREU,1989, p.45). 
Como se pode observar, o trajeto que compunha a Estrada Real, bem como seus arredores, unia em um "mesmo" território três capitanias de grande relevância para a época. Apesar de a extração do ouro e das pedras preciosas ocorrerem nas Minas Gerais, era imprescindível que a produção atravessasse uma das outras duas capitanias em direção ao oceano. Portanto, a ligação entre essas três capitanias era fundamental para que a produção aurífera mineira continuasse a ser escoada em direção à Europa.

Com isso, pensar em um território independente do domínio português seria considerar uma área de abrangência que se estendesse também a São Paulo e Rio de Janeiro. Os inconfidentes, em suas tentativas de firmar acordos com agentes políticos e pessoas influentes nessas duas capitanias, certamente pressupunham que as três capitanias, juntas, formariam uma Nação forte que seria capaz de se firmar e se sustentar independentemente da Coroa portuguesa.

Vale lembrar que, de nada adianta um território com a extensão que se tinha na capitania mineira se não houvesse ocupações e povoamentos que o solidificasse. A criação das vilas que ocorreu com maior intensidade na primeira metade do século XVIII, foi fundamental como salienta Fonseca (2011), para definir a hierarquia urbana mineira. Assim, com uma "rede urbana" minimamente estruturada, tornaria mais fácil garantir a unidade do território que contemplava o projeto de independência dos inconfidentes.

Cabe ressaltar que, se em um primeiro momento - o da ocupação dos sertões mineiros iniciado no século anterior - o intenso deslocamento de pessoas que se mobilizaram nessa empreitada era vantajoso, uma vez que, permitiu a descoberta de novas jazidas e posteriormente, tornou-se uma necessidade da Coroa portuguesa garantir que os viajantes se fixassem para facilitar a cobrança dos impostos e a vigilância sobre a circulação do ouro descoberto e explorado (FONSECA, 2011).

Ademais, a criação das vilas na segunda metade do século XVIII esteve ligada a fatores como "necessidade de justiças" (FONSECA, 2011), ou seja, a reivindicação da população dos arraiais em ter nas proximidades, juízes e tabeliães, para evitar longas viagens até as vilas. As fundações também estavam relacionadas às políticas governamentais que pretendiam expandir os limites da Capitania de Minas Gerais.

A preocupação com as fronteiras, principalmente as de São Paulo e Goiás, fez com que vilas fossem criadas como "uma estratégia de legitimação da posse dos espaços periféricos, que foi posta em prática pelos dirigentes de Minas Gerais" (FONSECA, 2011, p. 194).

A mineração foi, portanto, decisiva para estruturar os limites da capitania mineira, tendo sido a atividade mineradora o alicerce da economia e a responsável por definir os contornos daquele espaço antes inexplorado. Desde o povoamento inicial, que partia dos centros mineradores para as zonas circunvizinhas, caracterizado como "centrífugo" (FONSECA, 2011, p. 66), até meados do século XIX, com a criação de novas vilas em outras regiões da capitania, a mineração - ou a sua decadência, suscitando o fortalecimento de atividades como agricultura e pecuária, que tinham papel secundário - foi essencial para a evolução da malha territorial mineira.

\section{A INTENCIONALIDADE SUBJETIVAMENTE PRESENTE NO TEXTO DE CLÁUDIO MANUEL DA COSTA}

Os textos arcádicos se debruçavam na busca da verossimilhança. Como afirma Bosi (1980), estes se fundamentavam na "noção de arte como cópia da natureza" (BOSI, 1980, p. 62). A busca constante pelo realismo e pela valorização da verdade foi fundamental para sustentar as obras dos poetas inconfidentes, visto que, os textos são reflexos da percepção e da compreensão de cada autor sem, no entanto, perder de vista a realidade das Minas setecentistas.

A influência arcádica em textos de poetas mineiros se deveu, como apresentado anteriormente, ao fato de o Arcadismo ter se desenvolvido na Europa ao longo do século XVIII, servindo a esses poetas que trouxeram consigo os ideais lluministas, após concluírem anos de estudo no "Velho Mundo".

O lluminismo foi a explosão das ideias que valorizavam a racionalidade, desenvolvendo-se ao longo do século XVIII, o "Século das Luzes" e, espalhando-se por toda a Europa. Entretanto,

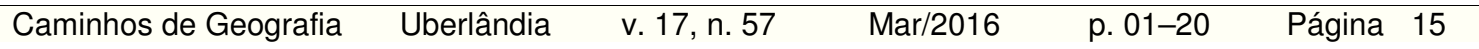


Alemanha, Inglaterra e França se destacaram dentre os demais países no que diz respeito às produções filosóficas e científicas da época, apresentando ao mundo, pensadores como Kant, Locke, Voltaire e Rousseau, respectivamente (ARANHA; MARTINS, 2003).

Os ideais de liberdade presentes na França lluminista do século XVIII se fortificaram diante da Revolução Francesa que, em 1789, levou operários, camponeses e burgueses para as ruas no intuito de derrubar o clero e a monarquia francesa, acabando assim, com o monopólio absolutista do Antigo Regime. Para Hobsbawn (1990) esse movimento é tomado como o marco inicial do estabelecimento dos nacionalismos na Europa. O autor salienta a Revolução Francesa foi um marco histórico para o estabelecimento dos nacionalismos - europeus ou não - sendo que, os demais movimentos pela independência que se seguiram, tomaram-na como base e construíram a partir dela sua própria nacionalidade. Como exemplo da influência francesa na fundação dos Estados nacionais daquele período, Hobsbawn (1990), afirma que:

Os EUA e a Austrália são exemplos evidentes de Estados-nações nos quais todas as características nacionais específicas e critérios de existência de nação foram estabelecidos desde o final do século XVIII, e de fato poderiam não ter existido antes da fundação de seus respectivos Estados e países (HOBSBAWN, 1990, p. 93).

Cabe enfatizar que 1789, ano da Revolução Francesa, foi também o mesmo ano da Conjuração Mineira, um dos movimentos de emancipação fora da Europa, influenciado pelos ideais franceses (ARANHA; MARTINS, 2003).

Destaca-se que havia, no entanto, certa incoerência entre as diferentes realidades do movimento lluminista na Europa e a proposta de independência dos inconfidentes, bem como, sua viabilidade de aplicação no contexto das Minas. Mesmo tendo a França entrado "no mundo moderno por uma via muito diferente" da inglesa, visto que, a nobreza francesa "tornou-se um apêndice decorativo do rei" enquanto a nobreza inglesa encontrou a "independência em relação à coroa" anos antes (MOORE JR, 1975, p. 63), ambos os países vivenciaram o lluminismo acompanhados pela Revolução Industrial. Enquanto que, nas Minas Gerais, assim como no Brasil colônia como um todo, o processo de industrialização não se apresenta naquele período.

Entretanto, Cláudio Manuel da Costa, em Vila Rica, expõe com clareza a influência desses ideais libertários, valorizando o direito do homem de gozar de sua liberdade. Estaria o autor antecipando os princípios que o levariam a participar do movimento pela independência das Minas Gerais?

Desconhecer inda a Justiça: a idade

Tem [ ] a humana inteligência

Para abraçar sem susto o que á violência:

Que tormento maior a um livre peito

Que a um homem, a um igual viver sujeito?

A liberdade a todos é comua;

Ninguém tão louco renuncia à sua.

As leis que um ente humano lhe prescreve,

Cego capricho sustentar-nos deve

Neste, diga-se embora fanatismo,

Embora seja abismo de outro abismo [...] (COSTA, 1996, p. 403, grifos nossos - 1aㅡ Edição, 1837).

Ademais, por vezes o autor remete-se às Minas Gerais como "nação" ou "pátria", reforçando ainda mais os ideais de liberdade que o moviam, uma vez que, os princípios por ele valorizados serão, posteriormente, direcionados ao movimento inconfidente. 
Houvera de lograr-se o ousado intento,

Mas o Gênio, que guarda as Pátrias Minas,

E seus descobridores de benignas

Influências enchera, percebendo

A crua idéia do atentado horrendo [...] (COSTA, 1996, p. 403, grifos nossos 1를 Edição, 1837).

Há que se ponderar aqui sobre a multiplicidade de sentidos que envolvem a palavra "pátria" ou "país", assim como apresentado por (DEL GAUDIO; PEREIRA, 2013). Segundo as autoras, isso se deve ao fato "país constitui um vocábulo que remete a algo para além de si mesmo, que une tempos e espaços diferentes e possibilita aos sujeitos se compreenderem como parte dos mundos sócio-históricos" (THERBORN, 1991 apud DEL GAUDIO; PEREIRA, 2013, p. 187). A "maleabilidade" da palavra poderia, portanto, estimular a "produção de exclusões, cartografias omissas, novos totalitarismos, fundamentalismos e colonização" (DEL GAUDIO; PEREIRA, 2013, p. 187).

Tendo sido conferido ainda, à país, o sentido de "nação" ou "lugar de nascimento", a escolha feita por Cláudio Manuel da Costa, ao referir-se às Pátrias Minas pode remeter a sua terra natal. No entanto, sabendo do envolvimento do poeta no movimento inconfidente e de seus ideais pela libertação da capitania mineira, resta-nos crer que as Pátrias Minas seriam uma alusão ao território que seria libertado.

Deve-se destacar aqui, a importância de Jean-Jacques Rousseau (1712-1778), filósofo de origem suíça que, vivendo na França durante o período que antecedeu a Revolução Francesa e tendo contato com as ideias liberais que borbulhavam no seio da sociedade europeia, desenvolveu discursos sobre a democracia, a desigualdade, o governo e a natureza humana. Uma de suas proposições mais conhecidas é a que trata do "estado de natureza", em que, os homens são considerados "sadios, bons e felizes" até que a propriedade privada separa os ricos dos pobres e gera desigualdade e miséria (ARANHA; MARTINS, 2003).

Se a preocupação popular com os abusos cometidos pela monarquia foi o sustentáculo da Revolução Francesa, a concepção política de Rousseau não era alheia a essa questão. Uma vez que o intento era (re)fundar o Estado Moderno - modelo de Estado estabelecido séculos antes, responsável por fortalecer os poderes da monarquia - Rousseau apresentou concepções democráticas acerca do poder, baseando-se em conceitos de "soberania popular" e "vontade geral". Seria possível, portanto, garantir que a vontade de todos fosse colocada acima da vontade de poucos, havendo apenas um povo para um território nacional. Ademais, Rousseau expõe suas ideias de maneira sensível sem deixar de lado o cunho racionalista. Estar envolto nos ideais lluministas o faz desenvolver teses que caracterizam a natureza humana em seu estado original, deixando entrever, ainda, os motivos pelos quais os homens foram corrompidos.

A preocupação com o estado natural dos indivíduos também é recorrente nas obras dos poetas arcadistas. Cláudio Manuel da Costa em suas "Obras" se preocupa em descrever a paisagem que tem diante de si comparando-a, entretanto, com a alma e os sentimentos do pastor que observa:

Destes penhascos fez a natureza

O berço, em que nasci: oh! Quem cuidara,

Que entre penhas tão duras e criara

Uma alma terna, um peito sem dureza! (COSTA, 1996, p. 95 - 1aㅡ Edição, 1768).

A intencionalidade e a preocupação em direcionar seus textos, seja para discutir questões relacionadas ao homem, à natureza ou à política, são recorrentes nas obras de Cláudio Manuel da Costa. Em seu poema Vila Rica - texto épico aqui tratado e que se propõe a exaltar a fundação de Vila Rica (atual Ouro Preto), a ocupação das Minas Gerais e suas belezas e

\begin{tabular}{|c|}
\hline Vaminhos de Geografia \\
\hline
\end{tabular}


riquezas naturais - há uma Carta Dedicatória ao Conde de Bobadela, Governador das Minas Gerais entre 1735 e 1752.

Protocolo integrante da retórica clássica, a carta dedicatória é a inscrição oficial e formal, no paratexto do livro, de uma homenagem, muitas vezes remunerada, a um superior e protetor. [...] Cláudio Manuel da Costa submetese naturalmente ao estatuto do escrito numa sociedade seiscentista, bem como às convenções do texto clássico, e endereça sua Carta Dedicatória ao marquês de Bobadela [...] (MUZZI, 1996, p. 351).

Cláudio Manuel da Costa, preocupando-se em agradecer ao Governador pela oportunidade que Ihe foi dada em advogar em Vila Rica e ocupar cargos administrativos na Capitania, demonstra em sua dedicatória clara gratidão pelos "benefícios" por ele recebidos. Em sua condição de "servo", o poeta exalta o "bom governo" de Gomes Freire - o Conde de Bobadela, que deixa satisfeito o povo e a monarquia.

[...] Há muito que ansiosamente solicito dar ao Mundo um testemunho de agradecimento aos benefícios que tenho recebido da Excelentíssima Casa de Bobadela. [...] Quem ignora que por quase trinta anos descansaram com felicidade nas mãos dos Exmos. Freires as Minas do Ouro do nosso Portugal? Quem não viu alegres os povos, satisfeito o Monarca e conseguida em toda a sua extensão a igualdade da Justiça por todo este espaço do saudoso governo daqueles Heróis? (COSTA, 1996, p. 357 - 1를 Edição, 1837).

Por outro lado, o poeta se interessa em levar seu poema, que é uma exaltação clara das "propriedades" naturais das terras mineiras, ao conhecimento de uma figura política influente. Pode se supor que ele, ao fazer o elogio da terra, valoriza as riquezas ali existentes e já antecipa um elemento central para a composição da identidade necessária à construção da Nação que almejavam os inconfidentes. De fato, era de extrema importância que um texto com tamanho conteúdo idealista estivesse em mãos de um agente político com poder de ação no Governo.

Ademais, ao construir um texto que reflete a "consciência de uma identidade cultural que não mais se confunde coma lusitana, e que se afirma gradativamente [...]" (MUZZI, 1996, p. 349), Cláudio Manuel da Costa coloca diante de seus leitores aspectos culturais, naturais e históricos que servirão de base para a construção de uma consciência nacional - ainda que incipiente diretamente relacionada com as Minas Gerais, que compõe a pátria almejada pelos inconfidentes ainda que, não englobando o Brasil colônia como um todo.

\section{CONSIDERAÇÕES FINAIS}

Ao transitar entre a ciência e a arte, deparamo-nos com o desafio de entrecruzar universos distintos que aparentemente, não se misturariam. E, ao voltar nosso olhar para textos literários que tanto tinham para revelar além da ficção, soubemos de imediato que o literato inconfidente Cláudio Manuel da Costa deixaria transparecer em seus escritos porções da realidade em que viveu, tal qual ela se apresentava, naquele espaço e tempo específicos.

Suas narrativas estavam repletas de concepções e visões do mundo e por mais fantasiosas que fossem, refletiam sua identidade e estavam pautadas em ideais, desejos e ideologias. Ao resgatarmos os discursos de Cláudio Manuel da Costa, foi possível apreender histórica e geograficamente a realidade das Minas Gerais setecentistas, bem como, as críticas, anseios e perspectivas de um indivíduo expressivo que se destacou por sua intelectualidade e sensibilidade afloradas.

O contexto social e histórico da região das Minas Gerais possuía conjunturas sociais, políticas e econômicas específicas. Caracterizada como uma região inóspita e desconhecida que assim permaneceu até que os metais preciosos fossem descobertos, o sertão passou a ser visto para além de seu qualificativo de lugar, mas sim, como uma condição, uma realidade a ser superada. A partir de então, a região se desenvolveu, recebeu grande contingente populacional e teve no "ciclo do ouro" um de seus momentos áureos, despertando o interesse de desbravadores, bandeirantes e também da Coroa portuguesa. 
Cláudio Manuel da Costa no épico Vila Rica procurou valorizar as belezas naturais das Minas Gerais, mostrando-se tão encantado por aquelas paisagens quanto pelas europeias, que outrora deixara para trás. Ao considerar as Minas Gerais como sua "pátria", o poeta deixa transparecer o desejo de ver aquelas terras independentes. Ademais, além de realizar uma descrição detalhada de algumas localidades - vilas e arraiais - que ocupavam posição estratégica no caminho das Estradas Reais, por onde circulavam as pedras preciosas, mostrou ser tarefa de fundamental importância, delimitar, mapear e valorizar o território que comporia a nação independente almejada pelos inconfidentes.

\section{AGRADECIMENTOS}

A CAPES - Coordenação de Aperfeiçoamento de Pessoal de Nível Superior, pela bolsa de Mestrado concedia à primeira autora.

\section{REFERÊNCIAS}

ABREU, J. C. Capítulos de História Colonial (1500-1800). Rio de Janeiro: Sociedade Capistrano de Abreu, Livraria Briguiet, 1954.

Caminhos antigos e povoamento do Brasil. Belo Horizonte: Itatiaia, 1989.

ALCIDES, S. Estes Penhascos: Cláudio Manuel da Costa e a paisagem de Minas (17531773). São Paulo: Hucitec, 2003.

ANSELMO, R.C.M.S. Literatura e Geografia: aproximações e distanciamentos. In: III Encontro Nacional de História do Pensamento Geográfico e I Encontro Nacional de Geografia Histórica, nov. 2012, Rio de Janeiro, RJ. Anais (magnético)... Rio de Janeiro, 2012.

ARANHA, M.L.A.; MARTINS, M.H.P. Filosofando: introdução à Filosofia. São Paulo: Moderna, 2003.

CÂNDIDO, A. Formação da literatura brasileira. Momentos decisivos. São Paulo: Martins, 1959.

. Iniciação à literatura brasileira. Rio de Janeiro: Ouro Sobre Azul, 2010.

CARVALHO, F.A. A Memória toponímica da Estrada Real e os escritos dos viajantes naturalistas dos séculos XVIII e XIX. In: 1ํ Simpósio Brasileiro de Cartografia Histórica, maio 2011, Paraty, RJ. Anais (magnético)... Rio de Janeiro, 2011.

CARVALHO, J.M. A formação das almas: o imaginário da República no Brasil. São Paulo: Companhia das Letras, 1990.

CÉSAR, G. Historiadores e críticos do Romantismo: A contribuição europeia, crítica e história literária. São Paulo: Editora da Universidade de São Paulo, 1978.

COSTA, A.G. (org). Os Caminhos do Ouro e a Estrada Real. Belo Horizonte: Editora da UFMG. Lisboa: Kapa Editorial, 2005.

COSTA, C.M. In: AGUIAR, M.S. (Org.) A poesia dos inconfidentes: Poesia completa de Cláudio Manuel da Costa, Tomás Antônio Gonzaga e Alvarenga Peixoto. Rio de Janeiro: Nova Aguilar, 1996.

DEL GAUDIO, R; PEREIRA, D.B. A Polissemia em torno do vocábulo Pays/País: entre Escalas, Estados e Nações. Boletim Goiano de Geografia, v. 33, n. 2, p. 185-201, maio/ago. 2013.

FONSECA, C. D. Arraiais e Vilas De'IRei: Espaço e Poder nas Minas Setecentistas. Belo Horizonte: Ed. UFMG, 2011.

FURTADO, C. Formação econômica do Brasil. São Paulo: Companhia Editora Nacional, 2003.

GOLDMANN, L. Dialética e Cultura. Rio de Janeiro: Paz e Terra, 1979.

HOBSBAWM, E. J. Nações e Nacionalismo desde 1780. Rio de Janeiro: Paz e Terra, 1990.

HOLANDA, S. B. de. Visão do paraíso: os motivos edênicos no descobrimento e colonização do Brasil. São Paulo: Brasiliense; Publifolha, 2000.

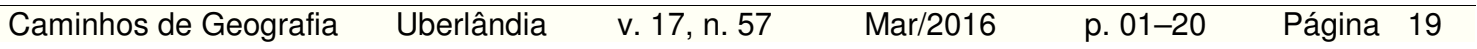


LAPA, M. R.; MUZZI, E. S.; RIBEIRO, J.; MALARD, L.; HELENA, L.; FIGUEIREDO, L.; BANDEIRA, M. I; AGUIAR, M. S. de; PEREIRA, P. R. D. FILHO, D. P. (Org.). A poesia dos Inconfidentes. Poesia completa de Cláudio Manuel da Costa, Tomás Antônio Gonzaga e Alvarenga Peixoto. Rio de Janeiro: Editora Nova Aguilar S.A., 1996.

LIMA JÚNIOR, A. de. A capitania das Minas Gerais (origem e formação). Belo Horizonte: Edição do Instituto de História, Letras e Arte, 1965.

MOORE JR, B. As origens sociais da ditadura e da democracia: senhores e camponeses na construção do mundo moderno. São Paulo: Martins Fontes, 1975.

MORAES, A. C. R. Território e História no Brasil. São Paulo: Annablume, 2008.

MURARI, L. Natureza e cultura no Brasil (1870-1922). São Paulo: Alameda, 2009.

MUZZI, E. S.; RIBEIRO, J.; MALARD, L.; HELENA, L.; FIGUEIREDO, L.; BANDEIRA, M.; LAPA, M. R.; AGUIAR, M. S.de; PEREIRA, P. R. D. FILHO, D. P. (Org.). A poesia dos Inconfidentes. Poesia completa de Cláudio Manuel da Costa, Tomás Antônio Gonzaga e Alvarenga Peixoto. Rio de Janeiro: Editora Nova Aguilar S.A., 1996.

PAULA, J. A. de. Raízes da modernidade em Minas Gerais. Belo Horizonte: Autêntica, 2000.

RESENDE, M. E. L. de. Inconfidência Mineira. São Paulo: Global Editora, 1983.

RODRIGUES, C. M. "Distrito Diamantino". In: BiblioAtlas - Biblioteca de Referências do Atlas Digital da América Lusa. Disponível em:http://hs.unb.br/biblioatlas/Distrito_Diamantino. Data de acesso: 23 de setembro de 2013.

SANTOS, M. Por Uma Geografia Nova. São Paulo: Hucitec, 1988.

SEVCENKO, N. Literatura como missão: tensões sociais e criação cultural na Primeira República. São Paulo: Brasiliense, 1983.

SILVA, J. N. de S. História da Conjuração Mineira. Tomo I. Rio de Janeiro: Imprensa Nacional, 1948.

VALADARES, V. M.T. Melo e Castro e sua inação quanto às Minas Gerais: a instrução de 1775 e a Governação de D. António de Noronha. In: Portugal e Brasil no Advento do Mundo Moderno. Lisboa: Edições Colibri, 2001. 